\title{
CHINESE DOCTORS IN THE DUTCH EAST INDIES: SOCIAL MOBILITY AMONG AN ETHNIC TRADING MINORITY IN A COLONIAL SOCIETY
}

\author{
H. Schijf and B.A.M. The
}

\section{Introduction}

In the Netherlands, as part of the colonial heritage, there live and work a number of doctors, dentists, and medical specialists of Chinese descent. ${ }^{1}$ Almost all these doctors, or their parents, were born in Indonesia, where the Chinese have constituted a trading minority for many centuries. Anxiety about their children's future in Indonesia generally provided their driving force for coming to the Netherlands, usually in the 1950s and 1960s. Most of their ancestors had emigrated from China to Indonesia many generations before. The doctors themselves grew up and went to school in the colonial period of the Dutch East Indies, studying medicine, either in Indonesia or in the Netherlands, somewhere between 1927 and 1950. In the then Dutch Indies they were, in most cases, the first members of their family to receive a Western education and to graduate from university. In this way they achieved a much higher educational level than their fathers, who had often received little schooling and were employed in trade. It should be remembered, however, that these graduates-including lawyers, engineers, and economists—only constituted a tiny minority of the Chinese trading minority.

Opting for the medical profession enabled the Chinese to advance themselves socially outside their own ethnic community. There are two different aspects to social improvement: education and professional status. The present article focuses on the first of these, giving a step-by-step description of the school careers of the respondents. Our reconstruction of the process of social mobility is based on twenty interviews with doctors who now live in the

This article is a revised version of H. Schijf en B.A.M. The, "Chinese artsen in Nederlands-Indie. Sociale mobiliteit bij een etnische handelsminderheid in een koloniale samenleveing," Amsterdams Sociologisch Tijdscrift, vol. 15 (3), December 1988, pp. 446-84. The text has been translated into English by R. Mesker and M. Springorum. We also wish to thank $W$. Icke for her editorial work.

1 Judging by the Indo-Chinese names in the Medical Address Book of 1986/87 among them were 54 Chinese doctors who had graduated before 1951. 
Netherlands. ${ }^{2}$ Data from interviews will be supplemented with statistical material from other sources in the text and in notes. Statistical material will counterbalance success stories related by the doctors. Obviously, the fact that they tell such stories about their school and college days follows from our selection: with one exception, we have spoken only with people who successfully completed secondary education and medical school. Yet not all Chinese pupils and students made it. Moreover, it should be borne in mind that the doctors in question were successful in yet another respect: they were able to emigrate to the Netherlands.

The doctors we interviewed regarded their parents' ambition to give their children a Western education as an important step in the process of social improvement:

The interesting thing is that even at that time [around 1915] my father was able to understand the position of the Chinese in the Dutch East Indies. One had to make a choice and my father opted for the European way. Of course, it required a great deal of self-conquest on his part to send me away from home-after all, I was the only son-and to put me up with a strange family. At the age of about six I was sent from Madura to middle Java. I wasn't allowed to see my father during the years I was at primary and secondary school. I had to be educated the Western way.

Admittedly, this is an exceptional story but, as we will show below, various other parents also went to great lengths to give their sons-sometimes their daughters too-a Dutch education.

It is not clear whether the medical profession provided the sons with a higher income than their fathers. Chinese parents who sent their children to Dutch schools were fairly welloff, but certainly not all the doctors' parents were rich. For them, the crucial point was that the medical profession provided a more secure and more stable income than trade. Moreover, the medical profession is often chosen because it provides security in times of discrimination: one is free to find work elsewhere.

\section{The Chinese Trading Minority in the Dutch East Indies}

\section{Migration}

The Chinese came to Java before the Dutch. But after 1870 "when large-scale Chinese immigration accompanied the extension of Dutch power over the whole of the archipelago and the resultant intensified exploitation of its resources ${ }^{\prime \prime} 3$ there was an augmented influx of migrants to the Dutch East Indies. Few of the doctors we interviewed came from families who had lived in the Dutch East Indies for less than three generations, and we met only one doctor whose father actually came from China himself. Certain migratory patterns may be distinguished among these doctors' ancestors insofar as they are known. For instance, some trading families settled in the Dutch East Indies only after several journeys there:

My grandfather on father's side still traveled up and down to China. He used to take children with him who went to school there. Then one day some of these kids stayed in Indonesia, and so did my father.

\footnotetext{
2 The doctors were born between 1910 and 1927. The two youngest graduated after Indonesia became independent. Four of them studied in the Netherlands, three at the Medical School in Surabaya (NIAS), while the remaining thirteen got their degree at the Medical School of Batavia.

${ }^{3}$ Charles A.Coppel, Indonesian Chinese in Crisis (Oxford University Press, 1983), p. 1.
} 
Another pattern was for an impoverished newcomer to set up a marginal business:

My grandfather came to Indonesia as an eleven-year-old boy. He at once started trading, like selling fireworks, together with his father. They set about as follows. In Semarang fireworks cost, let's say, ten cents. His father sold them at twelve. But fifty kilometers further on the same fireworks fetched double the price. So they used to go up there for a couple of days together. On his death my grandfather left as many as five tapioca plants and two oil plants. My father inherited these and expanded them.

Although trade was precarious, many different grandfathers could have related their own version of this story. ${ }^{4}$ For Chinese middlemen any crisis on the world markets of sugar, coffee, or rubber had disastrous consequences. Companies went bankrupt, thus forcing owners to start all over again. This illustrates that the financial development in a trading family was not always as successful as the above quotation might suggest. Earnings were often invested in houses which would in turn be inherited by the sons. Yet this transfer of wealth did not automatically ensure that the sons would be rich too:

My grandfather owned twenty or thirty houses. He had a pawnshop. Yet my father did not inherit a great deal for my grandfather had eighteen children [at that time rich Chinese often had more than one wife; it was a status symbol to have a few wives] and his property had to be distributed. Moreover, my grandfather used to spend rather a lot on opium. So my father only got three houses. In addition to this my father had a rice business.

Not all grandparents went to Java. Several doctors mentioned other islands where their ancestors had settled: Sumatra, Celebes, Madura, Ambon, and Bangka. In the nineteenth century a mining company started to mine tin on Bangka. Many Chinese were engaged to work in these mines, followed by another group of Chinese who earned their living from trade, and constituted another type of migration:

My grandfather owned a small paint factory for dyeing clothes. The miners needed clothes, which were usually black. The grandparents on my mother's side owned a small Indonesian foodshop. So my grandparents came to Bangka independently, not as contract laborers. My father owned some pepper gardens and rubber plantations on Bangka. It did not add up to much, but it was enough.

\section{Position and Trade}

Distinctions between Dutch, Indonesians, and Chinese were strict in the nineteenth century, particularly on Java: "the ruling class was largely Dutch, the middle class Chinese, and the lower strata Javanese. Social barriers of class tended to reinforce those of ethnic groups. Legal distinctions, moreover, followed ethnic lines and increased rigidity of the stratificational system." ${ }^{5}$ During the twentieth century, too, the Dutch-East Indian constitution recognized three social groups: Europeans, Natives, and Foreign Orientals. ${ }^{6}$ In compar-

\footnotetext{
${ }^{4}$ For further examples see D.E. Willmott, The Chinese of Semarang: A Changing Minority Community in Indonesia (Ithaca: Cornell University Press, 1960), pp. $46 \mathrm{ff}$. As important characteristics of the Chinese business Willmott mentions, amongst other things, its size (it was usually small enough to be run by one family) and a great diversity of trading activities.

${ }^{5}$ The Siauw Giap, "Religion and overseas assimilation in Southeast Asian countries," Reoue du sud est asiatique (1965), p. 77; see also W.F.Wertheim, East-West Parallels (The Hague: W. van Hoeve, 1964).

${ }^{6}$ This tripartite division is recognized in various statistics, although sometimes Chinese are mentioned, and sometimes Foreign Orientals only. It is also included in the educational statistics and registers of students at the three Academic Institutions.
} 
ison with the Europeans, this division initially imposed great legal inequality on the Chinese. As larger sections of European legislation began to be applied to the Chinese, this legal injustice gradually declined, although inequality in criminal law persisted. The Chinese were given the option of obtaining the same legal rights as Europeans ("gelijkgesteld" as the Dutch expression was), but criteria for granting this were continually subject to change: "Thus in 1871 a person was given equal rights on the basis of actual equality in language, clothing, religious way of life, employment and manners.(. ..)" After 1913 the central requirement for equality was shifted from "suitability for European society" to "the existence of legal requirements" and finally from 1917 onwards, these requirements were supposedly met by Chinese belonging to prominent families. In practice, this prominence often came down to a professional job or material well-being. ${ }^{7}$ Not many Chinese took advantage of the arrangement and the number who obtained equal rights before 1930 is estimated at only three thousand. ${ }^{8}$

However, almost 50 percent of the fathers of the doctors we interviewed had obtained equal rights. Obviously, the Chinese had divergent views on equality. Some spoke mockingly of "one-fifty Dutch" (the price of the stamp used for the request), while others regarded emancipated Chinese as "deraced Chinese." Even among well-off Chinese it was not customary to submit a request for equal rights. However, for Chinese working for the government it was thought acceptable, for the disadvantages in position and payment of not obtaining equal rights for them were quite considerable.

During the time of the East India Company the Chinese had appointed rulers of their own, called officers of the Chinese (majors, captains, and lieutenants) who were responsible for affairs in the Chinese quarters. The officers were unpaid, although expenses were covered and they occasionally received a commission from the salt distribution. In the 1920s and 1930s the value of these posts declined as a result of enhanced freedom of action for the Chinese who were increasingly coming under European law. Consequently people were less eager to become officers. ${ }^{9}$

About half of the doctors we interviewed had a grandfather or father who had held an administrative function in the Chinese community. Yet all respondents emphasize that in their fathers' days these functions no longer amounted to much. Be that as it may, it implied that their grandparents or parents were at least respectable, that their name and fame were unblemished, and that, one way or another, they were different from the "average" Chinese. Another major advantage of the post was the more frequent contact it involved with the Dutch and their administrative apparatus. None of the doctors' families held Western administrative or official posts, with one exception:

My father was the first Chinese alderman of Bandung, he later became deputy mayor. My father represented the Chinese community in Bandung. He was the one who had received an education at HBS level [equivalent to high school which was quite unusual for someone of his generation], spoke Dutch well, and could also speak some other languages; he was the obvious choice. Whether he was paid for the job or not, I don't really know. Anyway, he also owned a couple of factories, so we were always well-off.

\footnotetext{
${ }^{7}$ C.T. Bertling, "Gelijkstelling van Chineezen met Europeanen," Koloniale Studien 11, part 2 (1927): 60, 61. ${ }^{8}$ A. van Marle, "De groep der Europeanen in Nederlands-Indie, iets over ontstaan en groei," Indonesie 5 (19511952):104.

9J. Moerman, In en om de Chineesche kamp (Weltevreden: Kolff, 1929-II), pp. 54 ff.
} 
Not all Chinese were employed in trade in the 1930s. Java and Madura had the highest concentration in this sector: 54.7 percent of the Chinese labor force. ${ }^{10}$ With reference to the entire Dutch East Indies, 35.4 percent of the Chinese were employed in trade.

Like their grandfathers, most of the doctors' fathers were engaged in trade, that is dealing, importing, and exporting of rice and other Indonesian products. They were either wholesalers or typical middlemen. Yet, the professions of this generation, compared with earlier ones, had become far more diverse. Some fathers owned sugar or oil plants, and others possessed one or more Indonesian foodshops, a modern Western department store, or even a car business. Some families ran a batik workshop for sarongs-these were the kind of family businesses in which the mother often played a very active part. A few fathers owned and managed a large number of houses. One of the wives described how such property had come into their hands:

My husband's family was more wealthy than mine. But although my father may not have been captain of the Chinese or something like that, he was in comfortable circumstances. Of his eleven children five went to college in Batavia [she herself did not go to college], which was quite expensive. My father invested all his money in houses which he then rented out. At one stage he owned as many as 35 houses which, what with the proceeds from trade, added up to a considerable sum.

All the professional activities mentioned above are more or less characteristic of a trading minority. Yet during the fathers' generation other professions were already emerging, such as that of administrative assistant at a large car business or cashier at a Dutch Colonial Bank. A woman doctor mentioned that her father had been employed by the Dutch Railways; he had had technical training. Considering their sons' college education in the Netherlands or their membership of the student society in Batavia, some of these fathers must at least have been in comfortable circumstances; other fathers were not. Most of the fathers had had little schooling-not very surprising considering the lack of suitable schools in their childhood. Some had attended a Chinese school or had had some Dutch schooling for a couple of years. Only a few of them had attended or completed schooling at a MULO; one of them had a HBS-qualification.

In Chinese families, it was customary for a son, usually the eldest, to succeed his father in the business, a transfer which did not always go smoothly:

Remembering my father's stories I sometimes feel that we lack his kind of drive. Even the commercial spirit has become alien to us. In my childhood this was my greatest fear, for I was the eldest son. And as the eldest I was bound to be his successor. This evoked all kinds of unmerited homage from the population. I was not proud of it. On the contrary, I was left with the fear that one day it would all be mine.

In the end the father considered his son unsuitable for trade and he then decided to study medicine.

\footnotetext{
${ }^{10}$ Other important fields of employment were industry (20percent) and the production of raw materials ( 31 percent) (Coppel, Indonesian Chinese in Crisis, : p.19; these data are derived from the Volkstelling 1930, part VII, "Chineezen en andere Vreemde Oosterlingen in Nederlandschlndie," [Batavia: Landsdrukkerij, 1935]). However, they refer to the entire archipelago. Chinese producers of raw materials were to be found notably on Sumatra (50 percent of the Chinese labor force) which, had a great deal of contract laborers.
} 


\section{Chinese Students in Western Education}

\section{Command of Languages}

In the 1920s and 1930s command of Dutch was comparatively rare in the Chinese community. ${ }^{11}$ Obviously, the first generation of migrants spoke a Chinese dialect, but this became less common among later generations. At home they usually spoke a local Indonesian language or Malay. The doctors we interviewed said their grandparents either spoke no Dutch at all or had only a smattering of the language. On the whole their parents were more familiar with Dutch. Only in exceptional cases, however, was Dutch the standard language spoken in the home, e.g. if both parents had had a Dutch education, a rare thing in the 1920s.

Since few children had any command of Dutch, the doctors' parents often had to go to great lengths to ensure that their children learned to speak the language properly. In some cases children were lodged at an early age with a Dutch teacher's family. The following example is an extreme case:

My father wanted my brother and myself to have a European education at all costs. My father later admitted that this was a mistake. My brother and I were at primary school in Bandung, where we boarded with the headmaster. In this way we could learn the language and way of life. Just imagine, boarding with a family within five minutes' distance from my father's house! Only on Saturdays and Sundays were we allowed to go home.

The usual practice to familiarize Chinese children with the Dutch language was to send them to a suitable kindergarten. Once children were attending primary school the situation at home often changed. Fathers fluent in Dutch began to communicate with their children in that language and the children did the same when they were talking amongst themselves. When communicating with their mother the children also often spoke Dutch. She would answer either in her own language, Malay, or Javanese, or sometimes had no choice other than speaking some kind of Dutch. In most cases this created a bilingual, sometimes even a trilingual (a third language was used to communicate with servants) home environment. A situation which-in retrospect-did not seem to present any problems. Few doctors told us that they spoke Dutch at school and at college only.

Parents preferred their children to attend a Dutch school because a Chinese education had become complicated by manifold language problems. Yet, even more important was the fact that, compared with other types of education, Dutch education had a high status and it offered the best quality. Moreover, only through Dutch schooling could students qualify for higher education. Around 1920, however, not everyone was aware of this:

The idea actually originated from my father's grandfather who understood developments in colonial society. He told my father that he should try to give his children a different education. It was also my mother's ambition. This was due to her father who worked for the big company of Oei Tiang Ham in Semarang. This was a big city so he knew more than we did in our small village.

\footnotetext{
11 Volkstelling, part VII p.106: "People able to write Dutch are found mainly among those born in Dutch Indies" and on p.107: "It is quite clear that the younger generation is far more familiar with the art of writing than the older generation. This is even more apparent with women than with men. It may be said that lately the art of writing has become far more widespread particularly among those able to write in Dutch, and: "Of the people born here the percentage of those able to write Dutch is undoubtedly highest in Java and Madura followed by the outlying provinces, without Sumatra" (p.108).
} 
The parents' choice was also prompted by the realization that, if their children wanted to get ahead in Dutch-Indonesian society, they should focus on Dutch culture and language. Such were relations in colonial society:

A colony is characterized by struggle for survival. You were nothing if you hadn't been educated and couldn't more or less measure up to the ruling colonial administration. To gain a position within this society we were expected to have attended a Dutch school at least.

\section{Primary Education}

Dutch primary education in the East Indies included three types of schools: the Europese Lagere School (European Primary School) (ELS), the Hollandse Chinese School (the Dutch Chinese School) (HCS), and the Hollands Inlandse School (Dutch Native School) (HIS). ${ }^{12}$ In addition to public schools, mission schools played an important role. Their high standard was the reason why several doctors were sent to these schools.

In the course of the twentieth century the number of Chinese pupils attending Dutch schools rose considerably. In 1930 the number of Chinese pupils at Dutch-speaking schools was about $24,000 . .^{13}$ The rise was mainly the result of the increasing number of girls attending Dutch schools. ${ }^{14}$ Yet, by no means all Chinese children went to school in those days.

Loe Ping Kian worked out that in the year 1935, 98,000 out of 200,000 Chinese children in the age group 6-14 had attended school. Only a quarter of these went to a Dutch school. ${ }^{15}$ But for Indonesian children, the proportions were many times worse. In 1930, 71,618 Indonesian children were attending Dutch schools as compared with the 24,000 Chinese children. Thus, in absolute terms there were about three times as many Indonesian pupils but the proportion of Foreign Orientals attending Dutch-speaking primary schools was twenty times as high as that of autochthonous Indonesians. ${ }^{16}$

The European Primary School was set up for children of Dutch parents who were unable to send their children to the Netherlands. This school had the highest status and, compared with other schools, non-European pupils could gain a year by attending it. The number of Indonesian and Chinese pupils never amounted to more than 10-15 percent. Admission requirements for these non-European children were partly the result of colonial power relations. Children of the highest ranks ("Native heads of the population") were automatically admitted, as were children of majors and captains of the Chinese. If other Chinese parents wanted their children to attend an ELS, they had to submit a request. Whether or not the request was granted would strongly depend on the parents' social position in their home town. Non-European children were frequently tested in their knowledge of the Dutch language, and at least one of their parents was required to speak the Dutch language too. An exception was made for parents who had gained equal rights for, after all, they then had

\footnotetext{
${ }^{12}$ Each of the three types of education was primarily intended for the group bearing corresponding name. Each of the three schools, however, also included pupils from the other two groups of the population. European pupils at HCS and HIS were mostly Indo-European who had the European status-that is if they had been acknowledged by their father. See also Leo Suryadinata, "Indonesian Chinese Education: Past and Present," Indonesia 14 (October 1972): 49-71.

${ }^{13}$ S.L. van der Wal, Het onderwijsbeleid in Nederlands-Indie 1900-1940; een bronnenpublikatie (Groningen: Wolters, 1963), pp. $693 \mathrm{ff}$.

${ }^{14}$ W.J. Cator, "The economic position of the Chinese in the Netherlands-Indies" (PhD. dissertation Leiden: 1936), p. 86.

${ }^{15}$ W.R. van Diffelen, , "Het onderwijs voor Chinezen, Koloniale Studieen (1936), nr. 5 and 6, p. 42.
} 
the same rights as Europeans and their children were admitted without any ado. Almost half of the doctors we interviewed had attended such schools, although not all parents concerned had obtained equal rights. ${ }^{17}$ Rich Chinese who had not been granted equal rights also made sure that their children attended a European school. One of them tells how this was achieved:

Although my father had not gained equal rights I did not attend an HCS. How? Well, money opens many doors. I attended a Catholic private school and that was the solution. For the mission schools could not possibly say: we only take European pupils. It was precisely the irreligious that should be accepted. It was very expensive however. The usual school-fee was, I think, fl. 2.50 a month; my father always paid fl. 11.50. All millionaires' children were attending such Catholic schools. In this way equal rights [or a request] could be avoided while one's children were still able to attend a European school.

A. K. Pringgodigdo compared the performance of pupils coming from the three different groups. His survey was based on final report marks for reading, writing, and arithmetic at ELSs in the school year 1933/34 and shows that, as regards reading and writing, there were only slight variations in the results for the three groups. ${ }^{18}$ As for arithmetic, however, there were some truly striking differences: on the whole Chinese pupils did better than others.

All the remaining doctors we interviewed attended an HCS with one exception, the son of a Totok-Chinese:

I started at a Chinese school, which was my father's wish. When he died I was allowed to go to a Dutch school. The first was an HIS. This school had a lower status than the HCS but there weren't that many schools at Ambon. Moreover, there wasn't enough money to send me to the HCS. Yet, I was one of the best pupils and in my final years at primary school I was allowed to go to an HCS.

The HCS took a year longer because it included a preliminary class intended to familiarize the pupils with Dutch-speaking education. The school was not open to everyone: only children whose parents had an income of at least fifty guilders a month were admitted. ${ }^{19}$ Moreover, tuition fees could present a financial barrier. Tuition rates for ELS, HCS, and HIS were the same. The amount depended on the parents' income, but only European parents could be exempted from paying fees. ${ }^{20}$

For parents who wanted their children to receive secondary education after primary school there were several possibilities. For children who had attended the ELS it was comparatively easy to gain access to an HBS. Like everyone else Chinese children had to submit to an entrance examination. But:

\footnotetext{
${ }^{16}$ Coppel, Indonesian Chinese in Crisis, p.21.

${ }^{17}$ But even then, we were told, there could be variations. Sometimes a distinction was made between a first and a second ELS. The first ELS was attended by full-blooded Dutch pupils, the second ELS by Chinese, Indonesians, and Eurasians.

${ }^{18}$ A.K. Pringgodigdo, "Toelating van niet-europeesche leerlingen tot de Europeesche Lagere School," Koloniale Studieen (1940), p. 423.

${ }^{19}$ Van Diffelen, "Het onderwijs voor Chinezen," p. 42.

${ }^{20}$ De Kosten van het westersch onderwijs in verhouding tot de draagkracht der bevolking, (Publikatie 4 van de Hollandsch-Inlandsche Onderwijscommissie, Weltevreden, 1930), p.3.
} 
If you had attended the HCS or HIS you had to take two entrance exams [one to test command of Dutch]. Added to this, you had to take private lessons in Dutch in the final year of primary school or you would certainly not be admitted.

\section{Secondary Education}

The relative overrepresentation of Chinese pupils in relation to Indonesian pupils was even stronger in secondary education. The absolute number of Chinese pupils attending the prestigious Hogere Burger School (HBS) even exceeded that of Indonesian pupils. Table 1, however, shows that in 1924 the total number of Chinese and Indonesian pupils educated at the five-year HBS schools (four in number at the time) was very small, especially compared to the number of European pupils.

Table 1. Number of Students at HBS, 5-curr. in 1924

\begin{tabular}{|c|c|c|c|c|c|}
\hline \multicolumn{6}{|c|}{ Europeans } \\
\hline Pupils & Present & \multicolumn{2}{|c|}{ Promoted } & \multicolumn{2}{|c|}{ Not Promoted } \\
\hline & & & $\%$ & & $\%$ \\
\hline 1st form & 618 & 405 & 65.5 & 213 & 34.5 \\
\hline 2nd form & 383 & 250 & 65.3 & 133 & 34.7 \\
\hline 3rd form & 323 & 227 & 70.3 & 96 & 29.7 \\
\hline 4th form & 204 & 143 & 70.1 & 61 & 29.9 \\
\hline \multirow[t]{2}{*}{ Total } & 1528 & 1025 & 67.1 & 503 & 32.9 \\
\hline & Examinees & Passes & $\%$ & Failures & $\%$ \\
\hline Finals & 185 & 131 & 70.8 & 54 & 29.2 \\
\hline \multicolumn{6}{|c|}{ Natives } \\
\hline Pupils & Present & \multirow{2}{*}{\multicolumn{2}{|c|}{ 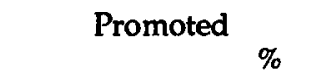 }} & \multicolumn{2}{|c|}{ Not Promoted } \\
\hline & & & & & $\%$ \\
\hline 1st form & 35 & 22 & 62.9 & 13 & 37.1 \\
\hline 2nd form & 27 & 22 & 81.5 & 5 & 18.5 \\
\hline 3rd form & 35 & 19 & 54.3 & 16 & 45.7 \\
\hline 4th form & 17 & 12 & 70.6 & 5 & 29.4 \\
\hline \multirow[t]{2}{*}{ Total } & 114 & 75 & 65.8 & 39 & 34.2 \\
\hline & Examinees & Passes & & \multicolumn{2}{|l|}{ Failures } \\
\hline Finals & 16 & 8 & 50.0 & 8 & 50.0 \\
\hline \multicolumn{6}{|c|}{ Chinese } \\
\hline Pupils & Present & \multirow{2}{*}{\multicolumn{2}{|c|}{ Promoted }} & \multicolumn{2}{|c|}{ Not Promoted } \\
\hline & & & & & $\%$ \\
\hline 1st form & 47 & 33 & 70.2 & 14 & 29.8 \\
\hline 2nd form & 26 & 19 & 73.1 & 7 & 26.9 \\
\hline 3rd form & 49 & 33 & 67.3 & 16 & 32.7 \\
\hline 4th form & 54 & 44 & 81.5 & 10 & 18.5 \\
\hline \multirow[t]{2}{*}{ Total } & 176 & 129 & 73.3 & 47 & 26.7 \\
\hline & Examinees & Passes & $\%$ & Failures & $\%$ \\
\hline Finals & 19 & 11 & 57.9 & 8 & 42.1 \\
\hline
\end{tabular}

Source: G. Révész, De overgang van het lager naar het middelbaar onderwijs en de plaats plaats van de middelbare school in het kader van het Nederlandsche schoolwezen (Groningen: Wolters, 1926), p. 86. 
In 1940, 553 Indonesian, 2,060 European, and 542 Chinese pupils attended an HBS. ${ }^{21}$ The system of secondary education was similar to that in the Netherlands in those days.22 On Java, HBS schools were only established in Bandung, Batavia, Malang, Semarang, and Surabaya. Medan housed the only HBS outside Java. For this reason many pupils had to follow a different course of education. First, they attended a MULO, and afterwards an AMS. There were several AMS schools, but, according to the doctors we interviewed, the Christian and Catholic AMS schools in Batavia occupied a central position. From all over the archipelago children came to these schools. Preselections at primary schools and MULOs had been so strict that their pupils were among the most competent and ambitious of their generation. In contrast with the HBS schools, there were fewer Chinese pupils than Indonesians at AMS schools. ${ }^{23}$ We have not met a single doctor who attended a HBS after the HCS; but we have met someone who went to a MULO, after attending ELS, and failing his HBS entrance examination. An important reason for parents not to send their children to HBS was the expense involved. Although it was usually easy to send children to a primary school in the immediate vicinity, in the case of secondary education this was more problematic. Therefore, out of sheer necessity, parents sometimes moved to a city where their children could go to school:

In 1932 my parents moved to Java [from Sumatra], only to be near the right school. My father set great store by his children's education, he'd do anything for it, even move to Batavia. This was quite a change, in fact a complete leap in the dark, as it was a time of economic crisis. It took my father a long time to find a job. In the end he started a small business of his own.

Another way of solving the problem was for the children to lodge with relatives, or, if this was not possible, with some other family, usually of Dutch nationality:

This meant a major transition: from an all-out Buddhist environment to the European milieu of a genuine Dutch Totok, a Christian family where they said prayers before dinner, for instance.

The great ambitions parents clearly cherished for their sons usually did not apply to their daughters, or to a limited degree only. A MULO in the near vicinity was thought to be sufficient. A doctor's wife comments:

I only attended a MULO. My sisters went to a MULO and Domestic Science School. I'd have liked to go on studying but I couldn't, in those days girls usually didn't. All the money was spent on my brother's education, for he was the family heir. To Chinese people sons are far more important than daughters.

As far as the doctors remember, contacts between the pupils of the three population groups at the ELS and HBS never posed any problems. There were communal games and sometimes the children went to each other's birthday parties. However, the attitude of teachers, usually full-blooded Dutch, was less predictable. Sometimes Chinese pupils were

\footnotetext{
${ }^{21}$ Van der Wal, Het onderwijsbeleid in Nederlands-Indie 1900-1940, p. 687.

${ }^{22}$ There were HBS schools with a three or five year curriculum and a few grammar schools. There were also state and denominatinal lower secondary schools with a curriculum of three years: MULO (More Comprehensive Elementary Education). Typical of the educational system in the Dutch Indies (there was no equivalent type of school in the Netherlands) was the AMS (General Middle School) with an educational level of upper Secondary School and a curriculum of three years and with the same exams as the HBS.

${ }^{23}$ In 1930,649 Indonesian, 164 European, and 237 Chinese pupils attended this type of school. In 1940 these numbers amounted to 922, 318, and 301 respectively. Ibid., p. 699.
} 
subjected to discriminatory remarks, at other times they were given preferential treatment by their teachers:

I did extremely well at the HBS. I was therefore able to go my own way and very often didn't go to classes. A teacher then told me: "for you it makes no difference but it's bad for the others, don't set a bad example". That same teacher wanted me to study in Holland, he said he'd see to everything.

It was possible to continue one's studies beyond the HBS and AMS. At this stage, a quite significant age gap had already developed between ELS-HBS graduates and those who had taken the HCS-MULO-AMS route. The fastest HBS pupils were then only seventeen years old, whereas the AMS graduates were already twenty or twenty-one years of age.

\section{Origin and Performance}

Relatively little statistical material about pupils of the three population groups is available. But extensive data were collected in 1929.24 As most of the doctors concerned were born between 1910 and 1927, a majority of them were attending school in 1929. Even though the data refer to a particular group of pupils in 1929 and are not entirely accurate, yet we think they give a fair indication of the social origin of Chinese pupils around 1930.

First of all, the enquiry results referring to the distribution of incomes per population group were compared with figures for each population group published by the Central Bureau for Statistics on the basis of income tax. These comparisons show that the income distribution for parents of European pupils virtually mirrors that of the entire European population. The same does not hold true for the Indonesian and Chinese pupils. With respect to the "Foreign Orientals" the Committee found: "that the more affluent parents were much better represented in comparison with people of the lower income brackets." As for the Indonesian pupils, the Committee observed "that the incomes of the Native pupils at the HIS are far higher than those of the mass of the native population." 25 Likewise, considerable differences in income were found among the pupils at the three types of primary schools. Those differences were even more conspicuous than in secondary education. The ELS, HBS, and AMS were mainly attended by Chinese pupils whose parents' incomes exceeded the fl. 1200.- limit employed by the Committee.

The difference in positions held by Indonesian and Chinese fathers is remarkable (as the Europeans occupied a very special place, they are not discussed here). Three-quarters of the Indonesian fathers were employed in public service, whereas about 70 percent of the Chinese fathers were self-employed. ${ }^{26}$

Many parents of Indonesian pupils were "Native heads of the population" or civil servants, whereas the Chinese fathers usually worked in trade.

\footnotetext{
${ }^{24}$ In 1929 the "Dutch-Colonial Education Committee" conducted a large-scale survey. No fewer than 749 primary and secondary schools were asked to supply information on the incomes and professions of the parents of pupils who had requested admission to the schools concerned for the first time in 1929.703 schools responded, supplying the Committee with data about 36,318 pupils, 9,611 of whom were rejected and 26,707 accepted at the various schools (Kosten 1930: p.I).

${ }^{25}$ Ibid. ${ }_{\iota}$ P. 2

${ }^{26}$ Het Leerlingenverloop en de bestemmingen der abiturienten bij de instellingen van westersch onderwijs in NederlandschIndie, 2 vols. (Publikatie 2 van de Hollandsch-Inlandsche Onderwijscommissie,Buitenzorg: 1929), p.24.
} 
The Committee also ascertained the efficiency of various school careers on the basis of combined school careers in primary and secondary education. 27 The Committee concluded: "that all nationalities perform better in the 5-year ELS-HBS course though shorter by one year, than in the ELS-MULO-AMS course, and that the Native and Chinese pupils in particular obtain markedly better results compared with the so-called "proper" route via HIS and HCS, while moreover the study period of the natives is shortened by two years. ${ }^{28}$

\section{Medical Studies}

\section{University Education}

University education was a recent phenomenon in the Dutch East Indies in the 1920s (formerly students were forced to go and study in the Netherlands; from 1910 some Chinese students were also studying in Holland). In 1920 the Bandung Polytechnic was founded. The Faculty of Law and the School of Medicine in Batavia followed in 1926 and 1927 respectively. And in the same year the Medical School was established, in addition to the already-existing Training School for Indian Doctors (STOVIA) which was abolished in 1936. ${ }^{29}$ In 1934 the status of the Medical School was recognized by law as equivalent to that in the Netherlands.

The Medical School attracted the largest number of students, reaching 632 in 1941 (figures from several Yearbooks of the three institutes). The number of Chinese students registered at any of the three institutes was disproportionally high in comparison with the percentage of Chinese people in the population as a whole. ${ }^{30}$ But the Medical School drew by far the largest number of Chinese students. When in 1927 it opened its doors, 27 freshmen enrolled including 12 Chinese students. Between 1933 and 1937 the composition of students remained stable: 35 percent Chinese, 45 percent Indonesians, and 20 percent Europeans. In 1941, 121 of the 632 students were European, 289 Indonesian, and 222 Chinese.

Apart from the Medical School in Batavia, there was yet another possibility for studying medicine in the Dutch East Indies: the Dutch-East Indian Medical School (NIAS) in Surabaya, founded in 1913. Entry requirements were less strict than for the Medical School. A MULO diploma sufficed, as the NIAS itself offered a three-year preparatory course. Many students had entered into an agreement with the colonial administration, thus ensuring that college expenses were covered. This medical school also showed a steady increase in its student numbers. In 1938, 362 attended the course there (no further details available). ${ }^{31}$

\section{Some Examples}

To summarize the above and to give an impression of the Chinese doctors we interviewed, we will now present three short biographies. The first is by a doctor who studied in the Netherlands:

\footnotetext{
27 Ibid.

28 Ibid.

${ }^{29}$ There were few Chinese at the STOVIA: of the 281 students registered in the academic year 1920/21, only seven were Chinese; the total number of Javanese students, by contrast, was 117.

${ }^{30}$ In 1937 the share of Chinese students at the Polytechnic amounted to 24percent (40 students). In 1938 Indonesian students constituted 66percent of the students at the Faculty of Law and Chinese students made up 18 percent(63 students).

31 We have only been able to find two Annual Reports of the NIAS, i.e. 1919 and 1920; other data are derived from the Colonial Report for 1930 and the Indian Report 1938.
} 
I was born in 1919 in a little village on the East coast of Java. My grandfather was a trader there. When I was four my parents moved to a bigger place for the sake of their children's future, where my father set up a car business. My parents didn't speak any Dutch. I only started speaking Dutch when I went to a kind of kindergarten, supervised by a Eurasian woman. My father didn't want to send us to a Chinese school because he always said: "if you want to get on in the world, you must go to a Dutch school." As we probably came from a well-to-do family, at least in that particular city, we were admitted to the ELS. I'm sure our parents had to submit a request, but it was granted before long.

In order to go to HBS I was put up with a Dutch family, some two-hundred kilometers further on. My father wanted us to go to college but he didn't care what subjects we chose. He was willing to sacrifice a lot for his children's education. My father's motive was that his children would be well-off in later life. "Not in trade," he would always say. Later my brother and I left for Holland to study medicine (my brother studied pharmacy). As the universities had been closed down by the Germans during the war, I didn't graduate in Leyden until 1947. I then went back to Indonesia, where I started to work in a hospital and subsequently set up my own practice.

Such a school career, followed by a study in the Netherlands, was rather unusual. Many of the doctors we interviewed studied medicine at the Medical School in Batavia:

In addition to operating a cinema in a medium-sized city on Java, my father owned a shop where he sold all kinds of things. That is what he did until the economic crisis began. Then my mother set up a batik business. My grandfather was captain of the Chinese and had obtained equal rights as this provided him with greater legal security. That's why he could already speak Dutch. When I was six, I went to an HCS together with my brother. The two of us went to a MULO. Eventually this school became a mission school run by the Brothers, since they taught most of the lessons. Because there were no HBS schools in small cities, you had to attend a MULO. Afterwards I went to the Catholic AMS in Batavia. In 1940 I started medical school in the same city. I was 20 years old at the time. Because of the Japanese occupation, my studies were interrupted for quite a while; I didn't graduate until after the war. I then set up my own practice.

The third doctor attended Medical School in Surabaya:

I was born in a tiny village in North Celebes. My father had a copra business which he'd bought up from the Indonesians. At home we spoke a Chinese dialect or Malay. I went to an HCS. In order to attend MULO, I had to move to a bigger place, where I took lodgings with a Dutch family. As 1929 was a time of crisis, my father was unable to pay for my training in Batavia. I therefore enrolled for the NIAS course, because you could get a scholarship for this type of education. If you were admitted, which depended on your grades in the MULO finals, a contract was made at once, binding you to work for the colonial administration after your graduation. The course was very bookish. If you got too many unsatisfactory marks for your quarterly tests, you were dismissed. The course took a minimum of nine and a half years, that is if you worked hard. After my training I worked as a doctor for the colonial administration and was sent to one of the outlying provinces, the central island of an archipelago. The Batavian doctors only wanted to work in Java. As a starting-NIAS doctor you were also paid less than those people from Batavia. However, for my trips between the islands I was given an extra allowance. 


\section{Choice and Financing}

Not all Chinese children were permitted to study: we have already indicated that sons sometimes had to take over their father's business. Younger sons-in exceptional cases daughters too-were allowed to pursue their studies, provided their results were satisfactory. The choice of medical school by so many Chinese students can largely be accounted for by the fact that there were few alternatives in the Dutch East Indies at the time. ${ }^{32}$ And an MA in law or in engineering usually held out the prospect of governmental positions, which were not popular with the Chinese and practically unattainable at that. ${ }^{33}$ Moreover, several doctors told us that they would actually have liked to study something else, for instance electrotechnology or agricultural engineering, but that their parents could not afford such a period of study in the Netherlands. Yet, many doctors who pointed out the lack of alternatives also believe that the study of medicine was very popular with the Chinese. The available data confirm this opinion: more than twice as many Chinese students enrolled at Medical School than at both the other two institutes. What were their motives?

Of course, those motives were partly individual: a choice perhaps prompted by an illness either they or a relative had experienced. In other cases it might be at someone's suggestion, for example the general practitioner, or:

Actually I wanted to become an engineer in Delft, but this was too expensive. His wife adds: Then the parish priest came, everybody always paid attention to his words and he said my husband should become a doctor.

In a few cases there was already a doctor in the family, who served as an example. A father's personal wishes also played a part:

My father had had a strong desire to become a doctor, but my grandmother would have none of it. He was the eldest son and becoming a doctor at the time meant living in Europe.

Grandmother was afraid my father would marry a Dutch woman. I remember he once asked me what I wanted to be when I was at primary school. I think I then wanted to become an engineer. "Well," he said, "you know I wanted to become a doctor, I'd be so happy if one of my children became a doctor." If he had said he wanted me to become a lawyer, I might have gone in for law.

The choice of parents to ensure that one of their children would study medicine sounds rather matter-of-fact:

My parents thought I was the best of their three children [two brothers and one sister], therefore I had to study medicine. My father said: "You go and study medicine, I know you can do it." It took all his money to pay for my studies in Holland and to enable me to specialize in Leyden afterwards.

In our introduction we observed that members of trading minorities tended to choose a university course that would allow them to become self-employed. This was also a very important factor for the doctors we talked to:

\footnotetext{
32 Among Chinese students in the Netherlands who, after all, had a far greater variety of choices, proportions among graduates were different: until 1943 the total number of graduates, i.e. 221, included 73 doctors and 18 pharmacists, but there were also 36 engineers, 48 lawyers, and 33 economists. Data supplied by Mr.A. van Marle in private communication.

${ }^{33}$ Kwa Thoan Sioe, "De Chineezen en de Westersche Geneeskunde,"in Feestbundel 1936 van het Geneeskundig Tijdschrift voor Nederlandsch-Indie (Batavia: n.p., 1936) pp. $276 \mathrm{ff}$.
} 
My father had decided I was to study medicine, for he thought I hadn't got the faintest notion of trade. He once told me: "choose a subject and a diploma that will hold good for the whole of your life. Money is easily spent." This is what he had probably experienced himself during the slump.

I think it is due to Chinese philosophy that so many Chinese people decided to study medicine. Their credo is: "Better to be your own boss in a small way than a servant in a big way." The Chinese don't like to have a master, they prefer to be self-employed.

I think the liberal professions are valued most. They are most secure and can be practiced anywhere in the world. That's why it was easy for me to go to Holland. People still find it a comforting thought that they can make a living anywhere in the world.

The decision to study medicine in Holland, in Batavia, or at school in Surabaya was mainly a financial matter. Parents had to be rather well-off to send their children to the Netherlands. For many of the students in Batavia or Surabaya this was certainly not the case. A survey held in 1933/34 among students of Medical School shows that the college expenses of many students were borne by two or more relatives. ${ }^{34}$ These data include all students. Some Chinese parents had to make heavy financial sacrifices as well:

When I began my studies, there was no money to cover tuition fees, i.e. a lump sum of three hundred guilders. With a great deal of effort we were finally allowed to pay by the quarter, i.e. seventy-five guilders. I know that at the time my father didn't earn more than seventy-five guilders a month at the most. However, father really went to great lengths to enable us to study. All my mother's jewelry had to be sold to pay for the bare necessities.

Two doctors mentioned that they had paid for their own education by taking on a variety of jobs. One of them mentioned that his father had recently died and that he was given a low grant only, just about enough to cover his tuition fees. The few data on this matter show that Chinese students in particular studied without the help of government grants. ${ }^{35}$ This indicates that not all Chinese students had such a hard time: some of them were from well-to-do families, others sometimes had relatives helping them out:

My father saw to it that the only son of his elder brother could study in Holland. This nephew later became an accountant for the KPM in Batavia. When my brother was ready to go to college, his studies were paid for by this nephew. Part of my studies were again paid for by my eldest brother. Moreover, I lived with my sister, so that I didn't have to pay board and lodgings.

The funding of studies in the case of the three NIAS doctors we discussed strongly differs from the above. When they started their studies all three of them had entered into an agreement with the colonial government, which provided them with a fair grant during their study period, but bound them to work for the government for a minimum of eight years after graduation. They made this agreement for purely financial reasons. One doctor reported that he did not have any other alternative after he had finished AMS. There was an economic recession and the price of pepper had fallen dramatically: his father was no longer able to pay for his studies in Holland. More or less the same holds true for the two others, who moreover had only attended MULO:

${ }^{34}$ Jaarboekje der Geneeskundige Hoogeschool te Batavia (Batavia, 1933), p.55.

35Jaarboekje (1933), p. 55. 
My father was in rather poor circumstances, so the idea was that I should look for a job after finishing school. I wanted to go to Commercial College but the money just wasn't there. Then my uncle from Surabaya happened to call on us and he said to me: "You come along with me to Surabaya and go to the NIAS to study medicine. I'll apply for a grant." I d never thought about such a thing before, indeed I didn't even know it was possible.

\section{University Study}

The Board of Governors scrupulously guarded the quality standard. The doctors remember that there were a lot of dropouts, especially in the first year:

The professors in my time [early 1930s] cracked jokes about it. There will be 110 of you in the dissecting room (after the first-year exam), but there is only room for 21 . So only 21 of you will be allowed to pass. Later a compromise was reached: four students were allowed to work on one body. The exams took place before or after the summer. I didn't think much about the selection, either: our subjects were chemistry, physics, botany and on the basis of your knowledge of these subjects it was decided who'd make a good doctor. The study took seven and a half years, longer than in Holland. We also had to learn how to extract teeth and how to cope with childbirth complications. After all, in a small village you'd be left to your own devices.

The percentage of students passing the first-year exam declined through the years, amounting to about 25 percent in the late 1930s. Once the first year was completed, chances of passing subsequent exams increased considerably: about 50 to 60 percent. ${ }^{36}$ Many a doctor we interviewed had to resit exams.

On one occasion the Board examined the performance of the three groups: "Starting from the total number of passes, including those who passed after one or more failures, the number for Europeans amounts to 81 percent, for Natives to 81 percent, and for Chinese students 86 percent." 37 The chairman commented: "This survey indicates that Chinese students come out best and our experience has taught us that this also applies to the second part of the bachelor $s$ exam. This might be attributed to the Chinese having a special aptitude for the study of medicine, it might also be that, compared with the other races, the Chinese population is better at selecting which matriculants are most suitable to study at Medical School.... In the long term, if social forces are allowed to take their course, our institute will mainly produce Chinese doctors." 38 This prediction, however, did not come true: the Chinese share, including graduates, continued to fluctuate around 35 per cent.

The reasons for failure at college were probably manifold, just like today. ${ }^{39}$ We only met two persons who discontinued their studies. One of them is a woman doctor, who gave up her medical studies in Batavia before the war ("I'd just had enough of it") and who became a nurse instead. She later moved to Holland, took up her studies again in 1945 and this time completed them. The other person is a lawyer who studied medicine in Leyden for one year but then decided to switch to East Indian law. His story illustrates once more that family pressure was often a decisive factor in the choice of a certain subject:

\footnotetext{
${ }^{36}$ Jaarboekje (1937), p. 55.

${ }^{37}$ Jaarboekje (1933), pp. 54 ff.

38Ibid., p. 59.

${ }^{39}$ There were good and bad years: in the first four years there was an output of over 50 percent but between 1934 and 1937 more than half of those registered for the first time discontinued the course (Jaarboekje [1941], p. 69).
} 
If my parents had had their way, I wouldn't have left for Holland at all, but would have joined the company instead. My brother [the eldest]—there were two of us at homehad to work for the company and wasn't even allowed to study. After one year I began to suffer from pangs of conscience: my study of medicine wouldn't be of any help to my family who owned a sugar enterprise. A lawyer would be more useful than a doctor.

When the study of medicine turned out to be a failure, some students switched to the study of law, even though this was considered inferior. ${ }^{40}$

Contacts between the three population groups were unstable. Some students only belonged to Chinese societies, some preferred the Students' Union, ${ }^{41}$ which included many Indonesians students, others again joined the mixed Catholic Students' Society. Student days as portrayed to us did not differ a great deal from those at present. As a result of the Japanese occupation many doctors' studies were delayed, just as the German occupation interfered with the progress of students in Holland. After their graduation, some physicians decided to specialize, sometimes in Holland, sometimes elsewhere, and sometimes not until many years later.

\section{Chinese Doctors}

According to the latest available data, those of August 1941, 231 medical students graduated from Medical School, ${ }^{42} 34$ percent of whom were Chinese students (78). But there were also doctors who had studied in Surabaya or Holland. We do not know the number of Chinese doctors working in the Dutch East Indies in 1941, but the situation in August 1938 is fairly easy to trace. ${ }^{43}$ In that year there were 47 Chinese doctors who had studied in Batavia, still including some who had been educated at the Training School for Indian Doctors; 44 of them had studied in Surabaya and 52 in Holland. We are also familiar with some facts about their employment: 112 doctors had their own practice, 20 doctors were employed by the colonial administration (19 former NIAS students), 3 were employed as medical officers, 6 as missionary doctors, while no data are available on the 2 remaining doctors.

Most doctors we talked to had their own practice, whether or not combined with a job in a hospital; in addition, some of them were also involved with teaching. Their practice was never confined to Chinese patients, but included Indonesians and Dutch, insofar as the latter still existed. The NIAS doctors were the only group to be in government service for a long time. Their Indonesian career consisted of continuous transfers, from one little village to another all over the archipelago. We have the impression that their lives were far from easy: "fortunately, I wasn't beheaded," one of them commented on his experience on Timor

Maybe there were financial reasons: there was an economic crisis going on and grants were no longer provided. $40 \mathrm{Up}$ to 1941 1,366 students had enrolled, 231 had graduated, 567 were still pursuing their studies, and $568 \mathrm{had}$ left college. Of the latter group 53 took up law, 9 went to a technical college, 5 to the NIAS, and 63 left for the Netherlands. It is not known whether they continued their studies overseas (Jaarboekje [1941], pp. 63, 64).

${ }^{41}$ In 1933 the Students' Society numbered 110 members including 23 Chinese (three of them studied law, the others medicine). Register in the Batavia Student Almanac 1933.

42 Jaarboekje [1941], p.63.

43Data counted in Geneeskundig Jaarboek; voor NederlandschIndie, 10e jaargang (Batavia: 1939). The list of addresses includes year and place of graduation, as well as function. The register is unlikely to be complete since it does not include doctors who were in the Netherlands at the time. However, we have not been able to find other lists. It has often been pointed out to us that the profession of pharmacist was popular among the Chinese as well, but in fact there were not really all that many (see also note 33): Tan (Tan Nio Sian, Zur Geschichte der Pharmacie in Niederlandisch-Indien (Indonesien) 1602-1945 [Wurzberg: JAL-Verlag, 1976]: pp. 236 ff.) mentions 15 Chinese who ran an independent pharmacy between 1900 and 1940. 
during the Japanese occupation. When their children became older, the doctors set out for Holland. Some of them only got there after many difficult years of wandering around.

\section{Conclusion}

In the 1930s the number of Chinese boys and girls who had attended a Dutch primary school-MULO, AMS, or HBS-was disproportionally high compared with the number of autochthonous Indonesians. Afterwards, only a few students-mainly men-continued their studies in Holland or in the Dutch East Indies. But perhaps we should emphasize once more that university education in the Dutch East Indies was rather limited. The greater part of the Chinese students opted for a medical education as this training offered them the best chance of pursuing a secure and independent career.

The social background of the doctors we talked to conforms with the characteristics of a classical ethnic trading minority. Their ancestors, who had nearly always emigrated from China at least three generations before, set up in trade. Many fathers were still employed in this sector. The economic progress of grandparents or parents enabled them to pay for Western education when this became available on a fairly large scale. Sometimes parents set such great store by a good education that they applied for equal rights-thereby risking the scorn of fellow-countrymen-in order to facilitate their children's admission to the European Primary School. All available statistical data indicate that, on the whole, Chinese pupils did better than Indonesian pupils but no better than children from the European upper classes. East Indian education, however, was characterized by a large turnover of pupils, including Chinese pupils, although the Chinese who finished their training were usually among the best of the graduates.

The fact that parents from Chinese or other trading minorities chose a strategy of individual mobility through education naturally does not exclusively apply to these parents. It is a choice made by many parents from a middle-class background on behalf of their children. Yet it is remarkable that Chinese minorities all over the world should be so successful in this respect. Charles Hirschman and M.G. Wong have analyzed this success of second and third-generation Chinese and Japanese migrants in the United States and observe: "Left to their own resources, Asians developed an ethnic economy that created an increasing number of jobs in trade and services. We suggest that this development was a major factor behind the educational gains of Asian-American children in the decades prior to World War II. Another factor is that Japanese and Chinese educational attainment seems to have "paid off" in occupational advancement even though Japanese and Chinese experienced considerable occupational discrimination. Education was a channel for the social mobility of Asians, partly because they were frozen out of some sectors of the economy and were forced to create their own occupational niches in the ethnic economy." 44 Hirschman and Wong point out some factors which also apply to the Chinese in the Dutch East Indies: occupational discrimination in some sectors, the creation of sufficient affluence to afford education, the use of education as a channel for a non-ethnic social ascent.

Nevertheless, the fact that the Chinese acquired Dutch education did not mean their complete assimilation to the Dutch; this was out of the question in a colonial society. Even nowadays, the doctors we interviewed (and their children as well) emphasize certain aspects of their Chinese identity, such as great diligence and ambition, no matter how Westernized they otherwise consider themselves to be.

\footnotetext{
${ }^{44}$ Charles Hirschman, and M.G. Wong, "The Extraordinary Educational Attainment of Asian-Americans: A Search for Historical Evidence and Explanations," Social Forces 65 (September 1986): 23.
} 